\title{
НОВЫЕ ХИРАЛЬНЫЕ АЗА-МАКРОЦИКЛЫ ИЗ ЛЕВОПИМАРОВОЙ КИСЛОТЫ
}

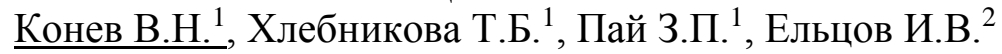

${ }^{1}$ ФГБУН ФИЦ Институт катализа им. Г. К. Борескова СО РАН, Новосибирск, Россия

${ }^{2}$ Новосибирский национальный исследовательский государственный университет, Новосибирск, Россия

konevv@catalysis.ru

DOI: $10.26902 / A S F E-11 \_78$

Природные хиральные соединения являются удобными и доступными строительными блоками в дизайне и синтезе хиральных катализаторов, реагентов для разделения и анализа смесей энантиомеров, фармацевтических и агрохимических препаратов. Дитерпеновые смоляные кислоты, содержащиеся в сосновой живице - многотоннажном продукте лесопереработки, являются привлекательным источником хирального сырья для синтеза практически значимых веществ. Однако, к настоящему времени возможности их геторофункционализации исследованы недостаточно.

B результате реализации разработанной нами стратегии $\mathrm{N}$-функционализации левопимаровой кислоты синтезирован оптически чистый диамин 1 [1]. На основе диамина 1 синтезированы хиральные лиганды, которые в составе комплексов меди(II) катализируют асимметрический вариант нитроальдольной реакции [2].

В настоящей работе из диамина 1 взаимодействием с рядом диальдегидов были получены с выходами 55-96\% аза-макроциклы 2-5 с разным размером олигоэфирного мостика. Исследование энантиодифференцирующих свойств полученных новых аза-макроциклов проводили титрованием рацемической миндальной кислоты синтезированными макроциклическими рецепторами 2-5. Было показано, что хиральные рецепторы 2-5 демонстрируют отчетливую способность к десимметризации энантиомеров миндальной кислоты. На рисунке представлен спектр ЯМР ${ }^{1} \mathrm{H}$ рацемической миндальной кислоты с добавкой макроцикла 4.

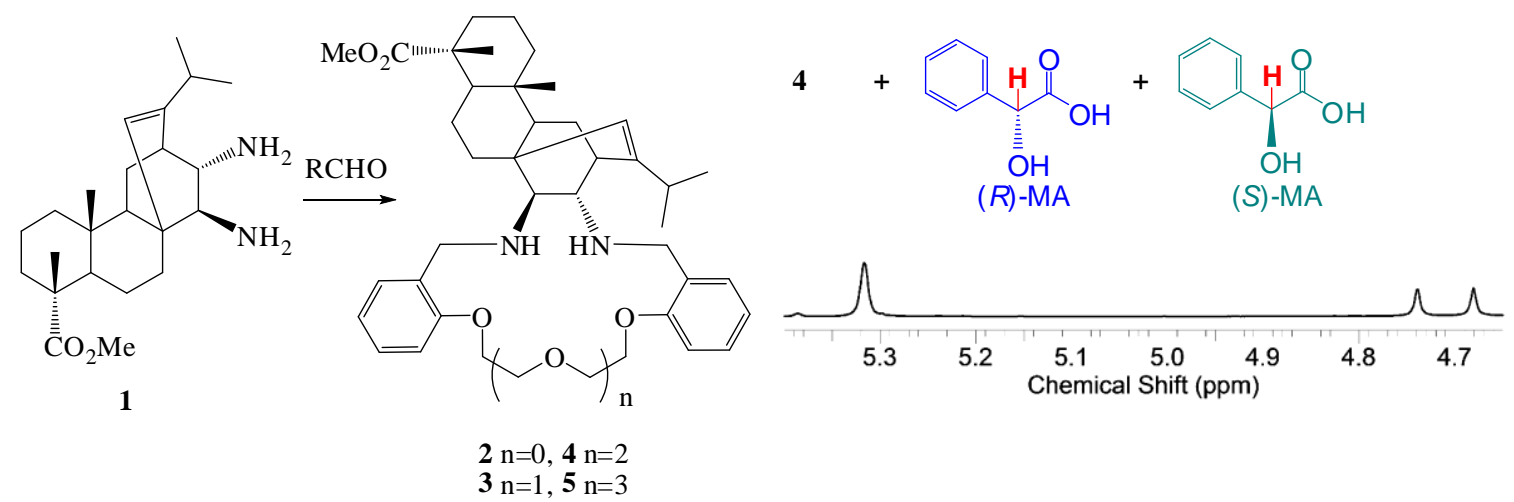

Таким образом, синтезированы в энантиомерно чистой форме новые макроциклические азотсодержащие полиэфиры с дитерпеновым фрагментом, и показана возможность их применения в качестве хиральных сольватирующих реагентов для определения оптической чистоты энантиомерных смесей миндальной кислоты методом ЯМР на ядрах ${ }^{1} \mathrm{H}$.

\section{Список литературы}

1. Конев В.Н., Хлебникова Т.Б., Пай З.П., Химия в интересах устойчивого развития. 2011. Т. 19. № 2. С. 165 168 .

2. Khlebnikova T.B., Konev V.N., Pai Z.P., Tetrahedron. 2018. V. 74. N 2. P. 260-267.

Работа выполнена при финансовой поддержке Министерства науки и высшего образования РФ в рамках государственного задания Института катализа СО РАН (проект ААAА-A21-121011390007-7). 